\title{
New distribution record, host plant and notes on natural history of Tomoplagia rudolphi (Lutz \& Lima, 1918) (Diptera: Tephritidae)
}

\author{
Marcoandre Savaris ${ }^{1,3} ;$ Felipe da Luz ${ }^{2,4}$; Lisete Maria Lorini ${ }^{2,5}$ \& Silvana Lampert ${ }^{1,6}$ \\ 1 Universidade de São Paulo (USP), Escola Superior de Agricultura "Luiz de Queiroz" (ESALQ), Departamento de Entomologia e Acarologia (LEA), \\ Laboratório de Taxonomia dos Insetos de Importância Agrícola, Programa de Pós-Graduação em Entomologia. Piracicaba, SP, Brasil. \\ 2 Universidade de Passo Fundo (UPF), Instituto de Ciências Biológicas (ICB), Programa de Pós-Graduação em Ciências Ambientais. \\ Passo Fundo, RS, Brasil. \\ ${ }^{3}$ ORCID: http://orcid.org/0000-0002-9145-6059. E-mail: savaris@usp.br \\ ${ }^{4}$ ORCID: http://orcid.org/0000-0003-1837-5882. E-mail: dlzfelipe@gmail.com \\ ${ }^{5}$ ORCID: http://orcid.org/0000-0001-9177-4711. E-mail: lisete@upf.br \\ ${ }^{6}$ ORCID: http://orcid.org/0000-0002-7930-0289. E-mail: lampert@usp.br
}

\begin{abstract}
In the state of Rio Grande do Sul, there are few records of geographical distribution and host plants to species of Tomoplagia Coquillett, as well as other genera of Tephritidae, especially those associated with plants of the family Asteraceae. Here, we report the first occurrence of Tomoplagia rudolphi (Lutz \& Lima, 1918) in the state of Rio Grande do Sul, inducing stem galls in Vernonanthura tweediana (Baker) H. Rob. (Asteraceae, Vernonieae), whose plant becomes a new host record for this species. In this way, is increased to nine species of Tomoplagia recorded for Rio Grande do Sul. Biological and morphological data and photos of gall, larvae, pupae at new host and distribution map of the species in Brazil are provided.
\end{abstract}

Key-Words. Tephritinae; Asteraceae; Vernonieae; Galls; Insect-plant interaction.

\section{INTRODUCTION}

Tomoplagia Coquillett, 1910 is an endemic New World genus of fruit flies with 61 species from the Neotropical and Nearctic Regions (Norrbom et al., 1999; Norrbom, 2010). In Brazil, Tomoplagia is the most diverse and abundant in the subfamily Tephritinae with 36 species registered for the southeastern, southern and midwest regions (Aczél, 1955a, b; Norrbom et al., 1999; Prado et al., 2002; Prado et al., 2004; Abreu et al., 2005; Uchoa, 2019).

The southeast region with 33 species has the greatest diversity within the genus, representing 91.6\% of the species that occur in Brazil (Lima, 1934; Fernandes et al., 1988; Norrbom et al., 1999; Prado et al., 2002; Prado et al., 2004; Abreu et al., 2005). The southern region with 11 species has $30.5 \%$ of the country's species (Norrbom et al., 1999; Garcia et al., 2002; Garcia, 2003; Prado et al., 2002; Prado et al., 2004; Sabedot et al., 2008; Sabedot-Bordin et al., 2011; Savaris et al., 2015). From the midwestern region only six species are reported, representing $16.6 \%$ of Brazil's species. The northern and northeastern regions have no records to the genus.
In the south, Santa Catarina stands out with the greatest diversity of species, being recorded: Tomoplagia biseriata (Loew, 1873), T. brasiliensis Prado, Norrbom \& Lewinsohn, 2004, T. costalimai Aczél, 1955, T. fibrigi Hendel, 1914, T. formosa Aczél, 1955, T. incompleta (Williston, 1896), T. minuta Hering, 1938, T. reimoseri Hendel, 1914, T. rudolphi (Lutz \& Lima, 1918), and T. vernoniae Hering, 1938, representing $90.9 \%$ of the specie's records from the region (Aczél, 1955b; Norrbom et al., 1999; Garcia et al., 2002; Prado et al., 2002; Prado et al., 2004; Sabedot et al., 2008; Sabedot-Bordin et al., 2011). In Rio Grande do Sul are recorded the following species: T. brasiliensis, T. costalimai, T. fibrigi, T. formosa, T. incompleta, T. matzenbacheri Prado, Norrbom \& Lewinsohn, 2004, T. minuta, and $T$. reimoseri, representing $72.7 \%$ of the region's species (Prado et al., 2002; Prado et al., 2004; Savaris et al., 2015). The state of Paraná has the lowest diversity with $27.2 \%$ of the species from the region. The species recorded from Paraná are T. brasiliensis, T. formosa, and T. rudolphi (Norrbom et al., 1999; Prado et al., 2002; Garcia, 2003; Prado et al., 2004).

Tomoplagia rudolphi was described from specimens reared from a gall on a plant of the genus 
Vernonia, in June of 1915, in Barreiros, São Paulo (Lutz \& Lima, 1918). In Brazil, it was recorded from the southeastern (Espírito Santo, Minas Gerais, Rio de Janeiro and São Paulo) (Aczél, 1955a, b; Andrade et al., 1995; Fernandes et al., 1988; Norrbom et al., 1999); southern (Paraná and Santa Catarina) (Aczél, 1955a, b; Norrbom et al., 1999) and midwestern regions (Mato Grosso) (Norrbom et al., 1999) (Fig. 1).

Most species of Tomoplagia are associated with host plants of the tribe Vernonieae (Asteraceae) (Prado et al., 2002; Prado et al., 2004; Sabedot et al., 2008; SabedotBordin et al., 2011; Savaris et al., 2015). There are a few records in the tribes Mutiseae, Heliantheae and rarely in other tribes of Asteraceae (Foote et al., 1993; Prado et al., 2002; Prado et al., 2004; Norrbom, 2010). Many species breed in flowerheads of the host plants, but an undescribed species was reared from an apical stem gall in Moquiniastrum polymorphum (Less.) G. Sancho (M. Savaris, n. publ.) and T. rudolphi from a stem gall in Vernonanthura polyanthes (Sprengel) Vega \& Dematteis (Fernandes et al., 1988; Andrade et al., 1995; Prado et al., 2002; Prado et al., 2004).

The interactions between Tephritidae and host plants, especially for species of the subfamily Tephritinae, are poorly known and still need to be better reported and clarified for the southern states in particular, as well as for the Brazil in general. In addition, the larval stages of Tomoplagia species are poorly known and just a few were described (Goeden \& Headrick, 1991; Andrade et al., 1995). Herein, we report for the first time the occurrence of T. rudolphi in Rio Grande do Sul in stem galls of Vernonanthura tweediana (Baker) H. Rob. (Vernonieae Cass.). Also, we include more information about the biological and morphological aspects of the third-instar larval.

\section{MATERIAL AND METHODS}

The study was realized in the Campus I of the Universidade de Passo Fundo (UPF), in the city of Passo Fundo, middle plateau region of the state of Rio Grande do Sul (28 $13^{\prime} 14^{\prime \prime} \mathrm{S}, 52^{\circ} 23^{\prime} 51^{\prime \prime} \mathrm{W} ; 687 \mathrm{~m}$; Fig. 1). The climate is considered Cfa in the Köppen classification, type humid and with hot summer (Alvares et al., 2013). The average temperatures are between 13.2 and $23.6^{\circ} \mathrm{C}$ with average annual precipitation of $1,800 \mathrm{~mm}$ and the average relative air humidity of $73.4 \%$ (Alvares et al., 2013; Embrapa Trigo, 2018).

The Campus I of Passo Fundo University has an area of approximately 380 ha. The vegetation is typical of Atlantic Forest (Mixed Ombrophilous Forest), characterized mainly by the presence of the "pinheiro-do-paraná", Araucaria angustifolia (Bertol.) Kuntze. Other parts of the Campus have ornamental and introduced plants such as eucalyptus (Eucaliptus spp.), privet (Ligustrum lucidum W.T. Aiton), cypresses (Cupressus spp.) and pinus (Pinus spp.) (Melo \& Severo, 2007). There are also agricultural areas that are mainly used for agronomic research, where crops of corn, soybean and wheat are grown. Asteraceae plants are found mainly in open and abandoned areas on the edges of small lakes, ponds, wetlands, forests and areas of crops.

The samples were collected between February 2017 and January 2018. Capitula and galls were collected as

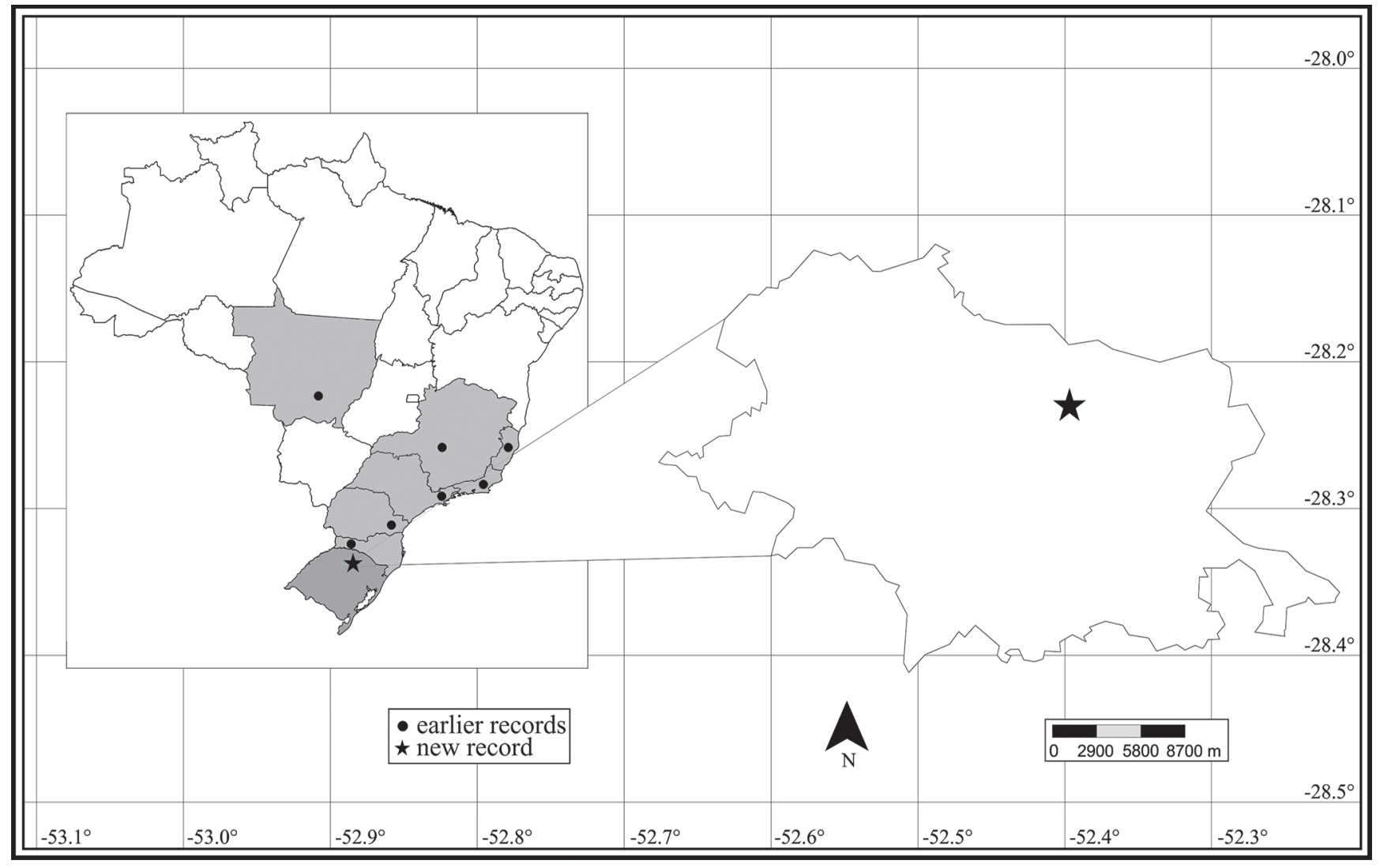

Figure 1. Distribution map for Tomoplagia rudolphi in Brazil. (๑) earlier records. ( $\star$ ) new record. 
possible host plants (Asteraceae) of fruit flies in the different types of environments of Passo Fundo University campus.

We found stem galls in plants of Vernonanthura ("mata campo"). These galls were collected, labeled, individually packaged in plastic bags and transported to the entomology laboratory of the Institute of Biological Sciences of the Passo Fundo University. The galls were placed in plastic vials of $180 \mathrm{~mL}$ and sealed with a screen cover. In each vial was placed a gall that remained stored until the emergence of flies. The vials were inspected every two days and any emerged adults were removed and mounted on entomological pins for identification.

The larvae sample was collected from galls. We obtained 15 larvae specimens, which were killed in boiling water for $1 \mathrm{~min}$ to distend the structures of the body, and preserved in $70 \%$ ethanol. For optical study, three larvae were treated overnight in $10 \% \mathrm{KOH}$ and dissected following the methods by Steck \&Wharton (1988). The cephalopharyngeal skeleton, the anterior and posterior spiracles were dissected and slide mounted for observations. Five larvae were separated for SEM examination, then dehydrated in ethyl acetate for 5 days, then air-dried, double mounted, and examined at National Museum of Natural History (USNM), Smithsonian Institution, Washington, DC, USA. The larvae description and measurements follow the terminology of Teskey (1981), White et al. (1999), Frías et al. (2006) and Steck \& Ekesi (2015).

Morphological study of adults was conducted with stereoscopic microscopy with dry and pinned specimens. The abdomens were removed with microforceps and macerated in a hot $10 \%$ sodium hydroxide for $5-8$ minutes. Some remaining tissue was removed and the terminalia transferred to glycerin for observation. The dissected abdomen was placed in a plastic microvial filled with glycerin and attached to the pin supporting the remainder of the insect from which it was removed. Adults were identified with the aid of entomological keys by Aczél (1955a, b), Norrbom (2010) and the original description (Lutz \& Lima, 1918).

Voucher specimens are deposited in the entomological collection of the Museu de Entomologia da Escola Superior de Agricultura "Luiz de Queiroz" - ESALQ, Universidade de São Paulo (numbers MELQ7087-1, MELQ7087-2, MELQ7087-3, MELQ7087-4, and MELQ7087-5) and entomological collection of the Universidade de Passo Fundo (CEUPF) of the Museu Zoobotânico Augusto Ruschi (MUZAR). The host plant vouchers were determined by Eraldo Barboza, Juarez Cordeiro and José Tadeu Weidlich Motta (MBM) and are deposited at Museu Botânico Municipal de Curitiba (MBM) and Herbário Rio Grande do Sul, Passo Fundo (RSPF).

The distribution map was made using Quantum GIS 2.8. Longitude and latitude were obtained for each locality, where galls were collected, using a Garmin 78S GPS receiver.

The larval and pupal illustrations are digital photographs taken using a camera Leica DFC 500 mounted on a Leica MZ16 stereoscopic microscopy; photographs were enhanced using Photoshop CS6 to adjust the color and make minor corrections (e.g., remove debris). Photos of galls were taken in the field with a Nikon D7200 camera. Scanning Electron Microscope (SEM) images were taken with a Hitachi ${ }^{\oplus \mathrm{TM}}$ TM3000 desktop unit (Tungsten source).

\section{RESULTS AND DISCUSSION}

We found 48 plant species of Asteraceae in 34 genera in Campus I of Passo Fundo University. We recorded 28 interactions between among species of 10 genera Tephritidae in flowers of Asteraceae. A previous study that inventoried Tephritidade in Passo Fundo recorded 102 species of Asteraceae in 64 genera and 29 associations between Tephritidae and host plants (Savaris et al., 2015). Our results in a less comprehensive area (Campus I only) represent $47 \%$ of the species recorded for the municipality and $96.5 \%$ of the interactions recorded by Savaris et al. (2015). Of the 28 insect/plant interactions recorded in this study, 27 were capitula of Asteraceae and only $T$. rudolphi was reared from stem, where the gall formation occurred. Savaris et al. (2015) in the same region recorded only interactions with capitula.

The galls were found in five plants ("mata campo"), which were identified as Vernonanthura tweediana (Baker) H. Rob. (Vernonieae Cass.). A single fusiform gall (Fig. 2A) was observed in the subapical region of the plant stem. The oviposition in the apical meristems of the stem by T. rudolphi may be related to the fact that the plant tissues are tender, facilitating the gall formation and also for containing greater amount of nutrients and amino acids used in cell differentiation (Fernandes, 1986; Andrade et al., 1995).

The galls found in plants of $V$. tweediana are similar to those that $T$. rudolphi induces in plants of $V$. polyanthes. Galls are spindle-shaped and green when young and become brown, glabrous, and unilocular when ripe. Gall formation induces the plant to produce smaller secondary branches, which form in the same gall (Andrade et al., 1995) (Fig. 2A, indicated by black arrow). The unilocular galls were opened to identify the presence of larvae (Fig. 2B) or pupae (Figs. 2D, 2H). The unilocular galls usually have several individuals together (Freidberg, 1984). This fact was observed by Andrade et al. (1995) in plants of $V$. polyanthes and by us in V. tweediana. We found 28 larvae/pupae from which emerged 11 adults, all identified as T. rudolphi. The occurrence of T. rudolphi in Rio Grande do Sul is a new record (Fig. 1). We also reported for the first time $V$. tweediana as a host plant for this species of Tephritidae, which was previously recorded as inducing galls only in V. polyanthes (Fernandes et al., 1988; Andrade et al., 1995).

We obtained an average of 5.6 larvae-pupae per gall of V. tweediana. Andrade et al. (1995) in Minas Gerais reported one to 12 larvae-pupae per gall in $V$. polyanthes. The larvae feed inside of the galls and form small side cavities (Fig. 2B), that reach the gall epidermis (Fig. 2C, indicated by yellow arrow). These cavities are for the adults to exit after emergence inside the gall. 

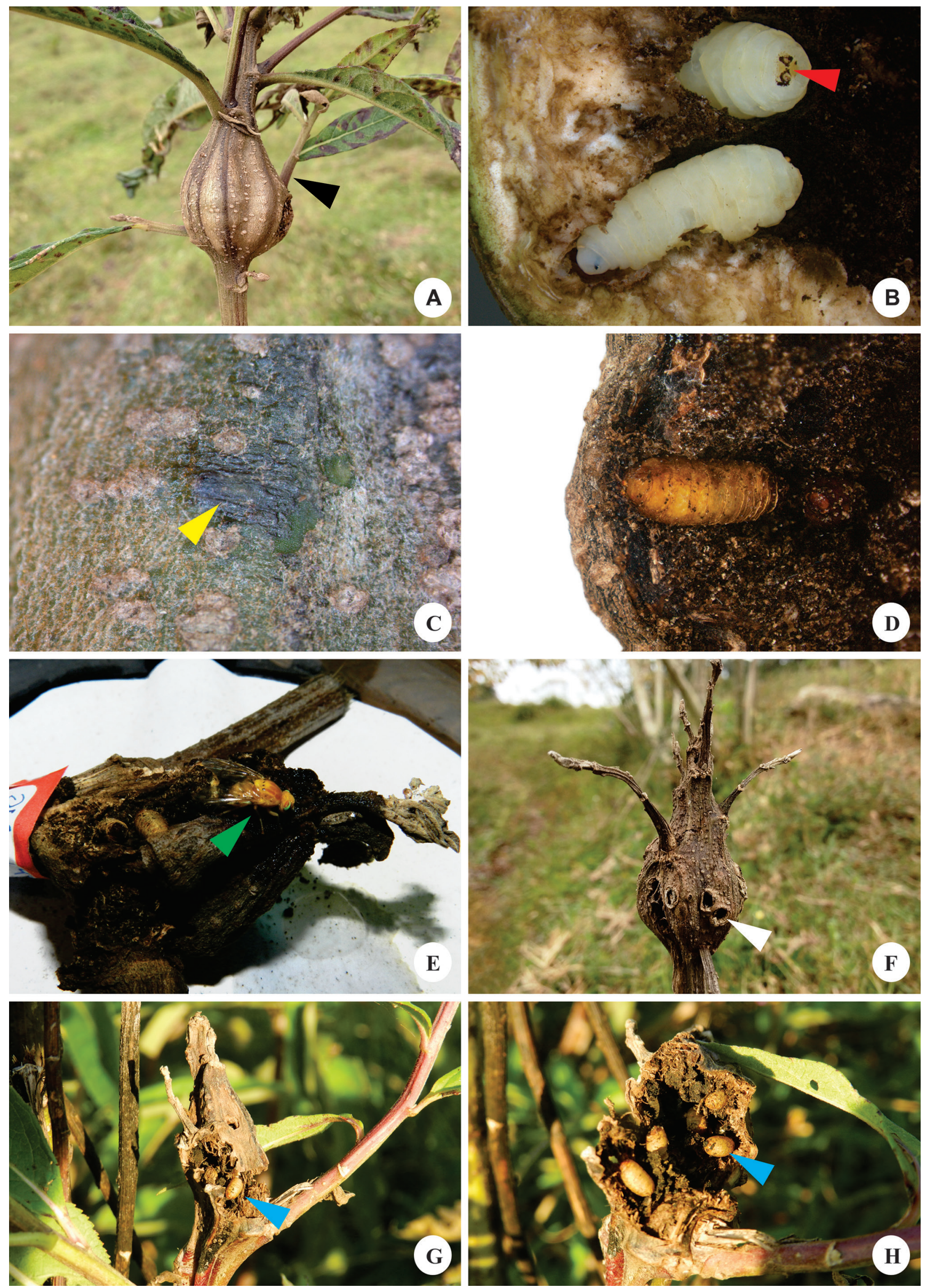

Figure 2. Biological aspects of Tomoplagia rudolphi. (A) gall; (B) larvae within of gall and damage; (C) indication in the mature galls of the future holes of fly exit; (D) pupae inside of the gall; (E) adult freshly-emerged; (F) old and dry galls with exit holes from adult insects; $(\mathrm{G}, \mathrm{H})$ larval feeding residues and old puparium. 

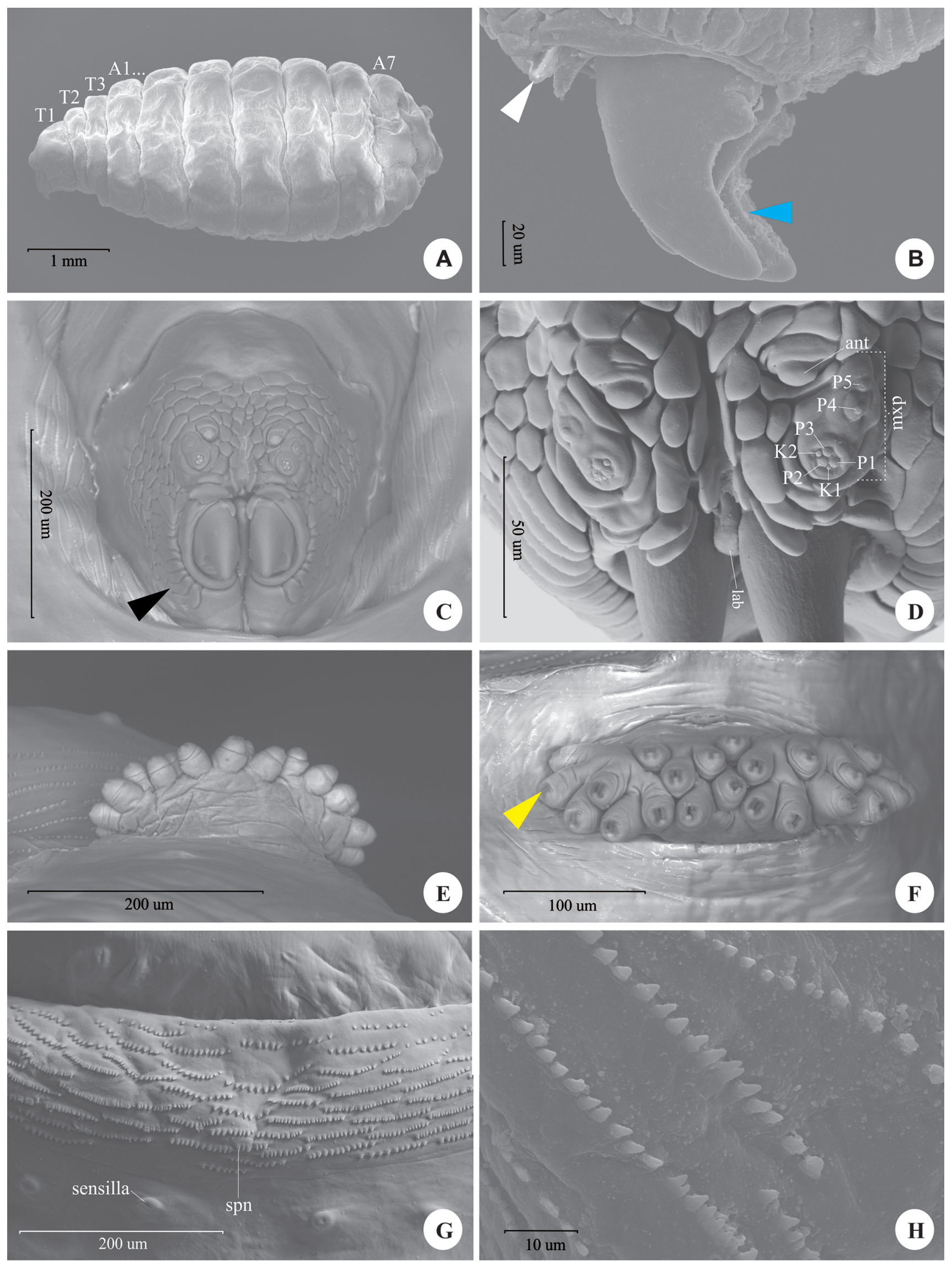

Figure 3. Scanning electron micrographs of larvae of Tomoplagia rudolphi. (A) habitus, lateral; (B) mouthhooks (preoral teeth indicated by white arrow); (C) head, ventral view (oral ridges indicated by black arrow); (D) antenna and maxillary palpus; (E) anterior spiracle, lateral view; (F) anterior spiracle, dorsal view (slitlike opening indicated by yellow arrow); $(\mathrm{G})$ rows of spinules on anterior margin of each segment; $(\mathrm{H})$ detail of the conical spinules. Abbreviations: $A 1=A 7=a b d o m-$ inal segments; ant = antenna; $\mathrm{K} 1, \mathrm{~K} 2=$ knob sensilla; lab = labium; $\mathrm{mxp}=$ maxillary palpus; $\mathrm{P} 1=\mathrm{P} 5=$ papila sensilla; prap th = preapical tooth of mouthhook; pror th = preoral teeth; $\mathrm{spn}=$ spinules; $\mathrm{T} 1, \mathrm{~T} 2, \mathrm{~T} 3=$ pro-, meso-, and metathorax. 

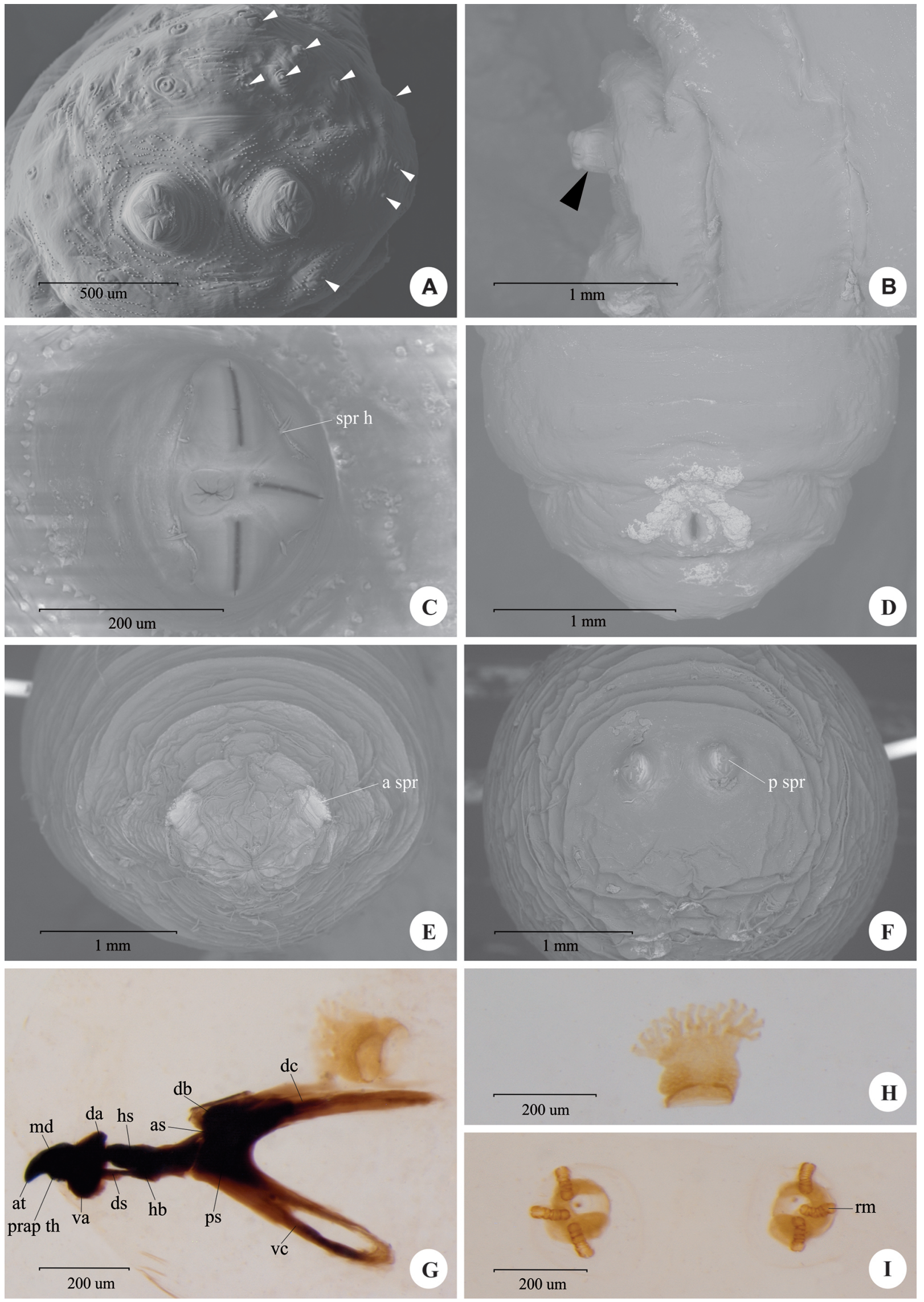

Figure 4. Scanning electron micrographs and photos of the larval of Tomoplagia rudolphi. (A) caudal segment; (B) posterior spiracle (tapered shape indicated by black arrow); (C) posterior spiracle, detail of the three respiratory openings; (D) anal opening; (E) pupa, frontal view; (F) pupa, posterior view; (G) cephalopharyngeal skeleton, lateral view; $(\mathrm{H})$ anterior spiracle, lateral view; (I) posterior spiracle, dorsal view. Abbreviations: a spr = anterior spiracle; as = anterior sclerite; at = apical tooth; $\mathrm{da}=$ dorsal apodeme; $\mathrm{db}=$ dorsal bridge; $\mathrm{dc}=$ dorsal cornu; $\mathrm{ds}=$ dental sclerite; $\mathrm{hb}=$ hypopharyngeal bridge; $\mathrm{hs}=$ hypopharyngeal sclerite; $\mathrm{md}=$ mandible; prap th = preapical tooth; $\mathrm{ps}=$ pharyngeal sclerite; $\mathrm{p} \mathrm{spr}=$ posterior spiracle; $\mathrm{rm}=$ rima; $s p r \mathrm{~h}=$ spiracular hairs; $\mathrm{va}=$ ventral apodeme; $\mathrm{vc}=$ ventral cornu. 
The third-instar larval of T. rudolphi was previously described by Andrade et al. (1995). Here we include more diagnostic characters of the third-instar of larvae, that are useful for the recognition of the species. Body length 7.3-9.2 $\mathrm{mm}(\mathrm{n}=10)$. The larvae are creamy-white in coloration (Fig. 2B), subcylindrical, tapering gradually to cephalic segment with integument intensely folded (Fig. 3A). The head dorsally has small and irregular plates (Figs. 3C, 3D), and the mouthparts are well developed and sclerotized (Figs. 3B, 4G). Mouth opening bordered with 8-10 rows of narrow and smooth oral ridges (Fig. 3C, indicated by black arrow), with anterior margin faintly ondulate (Fig. 3D). Labium is elongated and rounded apically (Fig. 3D). Antenna 2-segmented, smooth and rounded apically (Fig. 3D). Maxillary palp with 5 papilla sensilla and 2 knob sensilla, visible only by SEM (Fig. 3D). Cephalopharyngeal skeleton well developed; mandible black to dark brown with apical tooth rounded (Fig. 4G); mandibular tooth are curved, ventral surface smooth and grooved (Fig. 3B, indicated by blue arrow), with a minute subapical tooth (Figs. 3B, 4G); above of each mandibular tooth has a preoral teeth (Fig. 3B, indicated by white arrow); ventral apodeme black, broad and rounded, dorsal apodeme black and short; dental sclerite present; hypopharyngeal sclerite black; pharyngeal sclerite, anterior sclerite and dorsal bridge black to dark brown and strongly sclerotized; dorsal and ventral cornua anteriorly black to dark brown and posteriorly brown moderately sclerotized. Cephalopharyngeal skeleton length 0.91-1.05 mm, mandible tip to notch $0.48-0.62 \mathrm{~mm}$, dorsal cornu length $0.45-0.60 \mathrm{~mm}$, ventral cornu length 0.41-0.55 mm; mandible length a 0.17-0.22 mm, mandible length b 0.18-0.21 mm, mandible length c 0.12-0.15 mm, mandible height $0.14-0.16 \mathrm{~mm}$; hypopharyngeal sclerite length 0.15-0.21 mm, dorsal arch height 0.15-0.20 mm. Two anterior respiratory spiracles, projecting, usually with 19-24 tubules closely spaced (Fig. 4H), about as long as wide, rounded apically (Fig. 3E), arranged irregular in a double row, each with a slitlike opening apically (Fig. 3F, indicated by yellow arrow). Segments T1-T3 and A1-A8 with broken rows of conical spinules that encircles the body on anterior margin of each segment (Figs. 3G, 3H). Caudal segment white to pale yellow (Fig. 2B, indicated by red arrow), with 9 pairs of sensilla (Fig. 4A, indicated by white arrows), without a caudal ridge. Posterior spiracle, prominent with broken rows of conical spinules near base (Fig. 4A), tapered shape (Fig. 4B, indicated by black arrow), with 3 slit-like respiratory openings at the apex, dorsal and ventral slit vertically aligned, central slit in opposite direction (horizontal) to the other two (Figs. 4C, 4l); rimae 2.45-2.83 times as wide as long (Fig. 4l); spiracular processes little developed, usually with 1-2 branches (Fig. 4C). Anal opening without lobes (Fig. 4D).

Leavings from larval feeding remain in the unilocular cavity of the gall and the third-instar larvae pupate among the small excrement granules, preferably in the side cavities formed and close to the adult exit (Figs. 2D, 2H). Andrade et al. (1995) reported that the small excrement granules resulting from larvae feeding become hardened, and in the pupal stage the excrement granules separate one pupa from each other in galls of $V$. polyanthes. Pupae length $6.8-8.2 \mathrm{~mm}(\mathrm{n}=8)$. The pupae are rounded, with integument faintly folded, and have anterior and posterior respiratory spiracles larvae visible and prominent in the third-instar (Figs. 4E, 4F). The pupae are pale brown and remain protected inside the gall (Fig. 2D).

Adult emergence occurs inside the gall and the adult (Fig. 2E, indicated by green arrow) breaks the fragile epidermis (Fig. 2C, indicated by yellow arrow), which protects the opening of the holes of the gall with the head. In the old and dried galls found in the field, it is possible to observe adult emergence sites (Fig. 2F, indicated by white arrow). When galls are opened, it is possible to observe the damage caused by larvae, feeding residues, and old puparia (Figs. 2G, 2H, indicated by blue arrows).

The geographical distribution of T. rudolphi in Brazil (Fig. 1), follows the host plants distribution. Vernonanthura tweediana is found in the phytogeographic domains of Cerrado, Atlantic Forest and Pampa, occurring in the southern (Paraná, Rio Grande do Sul and Santa Catarina), southeastern (Minas Gerais and São Paulo), midwestern (Mato Grosso do Sul and Mato Grosso) and northeastern (Pernambuco) (Soares \& Almeida, 2015). Vernonanthura polyanthes occurs in the Cerrado and Atlantic Forest of the Southeast (Minas Gerais, Rio de Janeiro and São Paulo) and Northeast (Bahia) (Soares \& Almeida, 2015). It is possible that T. rudolphi occurs in Mato Grosso do Sul (midwest) and in the northeastern states, where there are confirmed records of host plants. The absence of such distributional data may be a sampling problem.

\section{CONCLUSIONS}

Until now, eight species of Tomoplagia are known in Rio Grande do Sul, and from the species which have host records, all are associated with capitula of Asteraceae. With this study we report ninth species of the genus namely $T$. rudolphi for the state, and for the first time a species of Tomoplagia is reported inducing stem galls in plants of $V$. tweediana. In addition, we report some biological and morphological data of $T$. rudolphi in $V$. tweediana galls, which were illustrated and may help in the gall, larvae and pupae recognition under field conditions. Although the amount/number of galls in the plants is low, T. rudolphi may have potential for biological control of $V$. tweediana, which is a common weed in disturbed sites, such as crops and pastures of southern Brazil.

\section{ACKNOWLEDGMENTS}

We thank Wayne N. Mathis (National Museum of Natural History, Smithsonian Institution) for the review of the English. Eraldo Barboza, Juarez Cordeiro and José Tadeu Weidlich (Museu Botânico Municipal de Curitiba - MBM) for identification of host plant. Caroline da Silva Ribeiro and Élinton Luis Rezende for assistance in the field. 
We thank the support from Programa de Pós-Graduação em Ciências Ambientais da Universidade de Passo Fundo (UPF) and Coordenação de Aperfeiçoamento de Pessoal de Nível Superior - Brasil (CAPES) - Finance code 001. We thank also the Programa de Pós-Graduação em Entomologia da USP/ESALQ and National Museum of Natural History, Smithsonian Institution. Also, we thank anonymous reviewers and the academic editor for improving the manuscript.

\section{REFERENCES}

Abreu, A.G.; Prado, P.I.; Norrbom, A.L. \& Solferini, V.N. 2005. Genetic and morphological diagnosis and description of two cryptic species of flower head-infesting Tephritidae (Diptera). Insect Systematics \& Evolution, 36(4): 361-370.

Aczél, M.L. 1955a. Fruit flies of the genus Tomoplagia Coquillet (Diptera: Tephritidae). Proceedings of the United States National Museum, 104: 321-411.

Aczél, M.L. 1955b. The comparative morphology of the Tomoplagia Coquillett species (Diptera, Trypetidae). Dusenia, 6: 139-170.

Alvares, C.A.; Stape, J.L.; Sentelhas, P.C.; Gonçalvez, J.L.M. \& Sparovek, G. 2013. Köppen's climate classification map for Brazil. Meteorologische Zeitschrift, 22(6): 711-728.

Andrade, G.l.; Silva, I.M.; Fernandes, G.W. \& Scatena, V.L. 1995. Aspectos biológicos das galhas de Tomoplagia rudolphi (Diptera: Tephritidae) em Vernonia polyanthes (Asteraceae). Revista Brasileira de Biologia, 4: 819-829.

Empresa Brasileira de Pesquisa Agropecuária (EMBRAPA - EMBRAPA Trigo). 2018. Informações meteorológicas. Available at: http://www.cnpt. embrapa.br/pesquisa/agromet/app/principal/agromet.php. Access in: 20/07/2018

Fernandes, G.W. 1986. Ecologia evolutiva de galhas de insetos: teoria e prática. Washington, D.C., Brazilian Embassy, Sector of Science and Technology.

Fernandes, G.W.; Neto, E.T. \& Martins, R.P. 1988. Ocorrência e caracterização de galhas entomógenas na vegetação do campus Pampulha da Universidade Federal de Minas Gerais. Revista Brasileira de Zoologia, 5: 11-29.

Foote, R.H.; Blanc, F.L. \& Norrbom, A.L. 1993. Handbook of the fruit flies (Diptera: Tephritidae) of America north of Mexico. Ithaca, Comstock Publishing Associates.

Freidberg, A. 1984. Gall Tephritidae (Diptera). In: Ananthakrishnan, T.N. (Ed.). Biology of Gall Insects. New Delhi, Oxford and IBH publishing Co. p. 129-167.

Frías, D.; Selivon, D. \& Hernández-Ortiz V. 2006. Taxonomy of immature stages: new morphological characters for Tephritidae larvae identification. In: International Symposium on Fruit Flies of Economic Importance From Basic to Applied Knowledge, 70. Proceedings. Salvador, SBPC. p. 29-44.

Garcia, F.R.M. 2003. Moscas-das-frutas (Diptera, Tephritidae) do Estado do Paraná, Brasil. Acta Ambiental Catarinense, 2: 35-40.

Garcia, F.R.M.; Campos, J.V. \& Corseuil, E. 2002. Lista documentada das moscas-das-frutas (Diptera, Tephritidae) de Santa Catarina, Brasil. Biociências, 10: 139-148.

Goeden, R.D. \& Headrick, D.H. 1991. Notes on the biology, hosts, and immature stages of Tomoplagia cressoni Aczel in Southern California (Diptera: Tephritidae). Proceedings of the Entomological Society of Washington, 93(3): 549-558.
Lima, A.M.C. 1934. Notas sobre Tripetidas brasileiras (II). Espécies cecidógenas da América do Sul (Diptera: Trypetidae). Arquivos do Instituto Biológico Vegetal, 1(2): 115-130.

Lutz, A. \& Lima, A.M.C. 1918. Contribuição para o estudo das Tripaneidas (moscas de frutas) brasileiras. Memórias do Instituto Oswaldo Cruz, 10: 5-15.

Melo, E.F.R.Q. \& Severo, B.M.A. 2007. Vegetação arbórea no Campus da Universidade de Passo Fundo. Revista da Sociedade Brasileira de Arborização Urbana, 2: 76-87.

Norrbom, A.L. 2010. Tephritidae (Fruit Flies, Moscas de frutas). In: Brown, B.V.; Borkent, A.; Cumming, J.M.; Wood, D.M.; Woodley, N.E. \& Zumbado, M.A. (Eds.). Manual of Central American Diptera. Ottawa, NRC Research Press. v. 2, p. 909-954.

Norrbom, A.L.; Carroll, L.E.; Thompson, F.C.; White, I.M. \& Freidberg, A. 1999. Systematic database of names. In: Thompson, F.C. (Ed.), Fruit Fly Expert Identification System and Systematic Information Database. Vol. 9, Myia, p. 65-251.

Prado, P...; Norrbom, A.L. \& Lewinsohn, T.M. 2004. New species of Tomoplagia Coquillett (Diptera: Tephritidae) from capitula of Asteraceae in Brazil. Neotropical Entomology, 33: 189-211.

Prado, P.I.K.L.; Lewinsohn, T.M.; Almeida, A.M.; Norrbom, A.L.; Buys, B.D.; Macedo, A.C. \& Lopes, M.B. 2002. The fauna of Tephritidae (Diptera) from capitula of Asteraceae in Brazil. Proceedings of the Entomological Society of Washington, 104: 1007-1028.

Sabedot, S.M.; Garcia, F.R.M.; Bogus, G.M. \& Savaris, M. 2008. Primeiro registro de Tomoplagia reimoseri Hendel e Xanthaciura mallochi Aczél (Diptera: Tephritidae) para 0 Estado de Santa Catarina, Brasil. Ciência Rural, 38: 1762-1764.

Sabedot-Bordin, S.M.; Bugus, G.M.; Bampi, D. \& Garcia, F.R.M. 2011. Tefritídeos endófagos (Diptera: Tephritidae) associados à Asteraceae em Chapecó, Santa Catarina. Biotemas, 24: 15-20.

Savaris, M.; Lampert, S.; Lorini, L.M.; Pereira, P.R.V.S. \& Marinoni, L. 2015. Interaction between Tephritidae (Insecta, Diptera) and plants of the family Asteraceae: new host and distribution records for the state of Rio Grande do Sul, Brazil. Revista Brasileira de Entomologia, 59: 14-20.

Soares, P.N. \& Almeida, G. 2015. Vernonanthura in Lista de Espécies da Flora do Brasil. Jardim Botânico do Rio de Janeiro. Available at: $\underline{\text { http:// }}$ floradobrasil.jbrj.gov.br/jabot/floradobrasil/FB27462. Access in: $5 \mathrm{dez}$. 2018.

Steck, G.J. \& Ekesi, S. 2015. Description of third instar larvae of Ceratitis fasciventris, C. anonae, C. rosa (FAR complex) and C. capitata (Diptera, Tephritidae). ZooKeys, 540: 443-466.

Steck, G.J. \& Wharton, R.A. 1988. Description of immature stages of Anastrepha interrupta, A. limae and A. grandis (Diptera: Tephritidae). Annals of the Entomological Society of America, 81: 994-1003.

Teskey, H.J. 1981. Morphology and terminology - larvae. In: McAlpine, J.R.; Peterson, B.V.; Shewell, G.E.; Teskey, H.J.; Vockeroth, J.R.; Wood, D.M. (Eds.). Manual of Nearctic Diptera. Ottawa, Canadian Government Publishing Center. v. 1, p. 65-88.

Uchoa, M.A. 2019. Tephritidae. In: Catálogo Taxonômico da Fauna do Brasil. PNUD. Available at: http://fauna.jbrj.gov.br/fauna/faunadobrasil/7890. Access in: 12 jul 2019.

White, I.M.; Headrick, D.H.; Norrbom, A.L. \& Carroll, L.E. 1999. Glossary. In: Aluja, M. \& Norrbom, A.L. (Eds.). Fruit flies (Tephritidae): phylogeny and evolution of behavior. London, CRS Press. p. 881-920. 